\title{
Use of allopurinol with low-dose 6-mercaptopurine in inflammatory bowel disease to achieve optimal active metabolite levels: A review of four cases and the literature
}

\author{
Todd N Witte MD, Allen L Ginsberg MD
}

TN Witte, AL Ginsberg. Use of allopurinol with low-dose 6-mercaptopurine in inflammatory bowel disease to achieve optimal active metabolite levels: A review of four cases and the literature. Can J Gastroenterol 2008;22(2):181-185.

BACKGROUND: At least one-third of patients with inflammatory bowel disease do not respond or are intolerant to therapy with 6-mercaptopurine (6-MP). A subgroup fails to attain optimal levels of 6-thioguanine nucleotide (6-TGN) and instead shunts to 6-methylmercaptopurine nucleotide (6-MMPN).

PATIENTS AND METHODS: A retrospective chart review was conducted, and four patients are described who had been previously unable to achieve optimal 6-TGN metabolite levels until allopurinol was added to their treatment.

RESULTS: All four patients achieved optimal 6-TGN levels and undetectable 6-MMPN with a mean $6-\mathrm{MP}$ dose of $0.49 \mathrm{mg} / \mathrm{kg}$. Three achieved steroid-free clinical remission. Two of those three patients had normalization of liver enzymes; one patient had baseline normal liver enzymes despite an initial 6-MMPN level of $27,369 \mathrm{pmol} / 8 \times 10^{8}$ red blood cells. Two patients experienced reversible leukopenia.

CONCLUSIONS: Combination allopurinol and low-dose 6-MP is an effective means to achieve optimal metabolite levels and steroidfree clinical remission in previously refractory patients. Caution is advised.

Key Words: 6-Mercaptopurine; 6-Thioguanine; Allopurinol; Inflammatory bowel disease; Metabolites

\section{Utilisation de l'allopurinol avec la}

6-mercaptopurine à faible dose dans la maladie inflammatoire de l'intestin pour l'obtention de taux optimum de métabolites actifs : Revue de quatre cas et survol de la littérature

HISTORIQUE : Au moins le tiers des patients atteints de maladie inflammatoire de l'intestin ne répondent pas au traitement par 6-mercaptopurine (6-MP) et un sous-groupe n'atteint pas de taux optimum de nucléotides de la 6-thioguanine (6-TGN) et présente plutôt des nucléotides de la 6-méthyl-mercaptopurine (6-MMPN).

PATIENTS ET MÉTHODES : Les auteurs ont procédé à une revue rétrospective des dossiers et décrivent quatre cas où il était impossible d'obtenir des taux optimum du métabolite 6-TGN jusqu'à ce que de l'allopurinol soit administré en traitement d'appoint.

RÉSULTATS : Avec une dose moyenne de 6-MP de 0,49 mg/kg, les quatre patients ont obtenu des taux optimum de 6-TGN et des taux indécelables de 6-MMPN. Trois d'entre eux ont obtenu une rémission clinique sans corticothérapie. Deux de ces trois patients ont vu leurs enzymes hépatiques se normaliser. Un patient présentait des enzymes hépatiques normales au départ, malgré un taux initial de 6-MMPN de $27369 \mathrm{pmol} / 8 \times 10^{8}$ globules rouges. Deux patients ont présenté une leucopénie réversible.

CONCLUSION : Ensemble, l'allopurinol et la 6-MP à faible dose constituent un moyen efficace d'obtenir des taux optimum de métabolites et une rémission clinique sans corticothérapie chez des patients auparavant réfractaires. La prudence est de mise.
The successful use of 6-mercaptopurine (6-MP) was first 1 reported by Present et al (1) more than two decades ago. Approximately two-thirds of patients respond to appropriate dosing; however, one-third of patients fail to respond or are intolerant of therapy.

Azathioprine (AZA) and 6-MP are inactive prodrugs that are metabolized by three principal pathways (Figure 1). 6-MP can undergo catabolism intracellularly to the inactive metabolite 6-methylmercaptopurine, or anabolism to the active metabolites 6-thioguanine (6-TGN) and 6-methylmercaptopurine nucleotide (6-MMPN). 6-Methylmercaptopurine and 6-MMPN are formed via the enzyme thiopurine methyltransferase (TPMT). There is interpatient variability in the degree of TPMT enzyme activity, with the majority of patients having 'normal' (high) activity (2). 6-TGN is formed via the enzymes hypoxanthine phosphoribosyltransferase and inosine monophosphate dehydrogenase. Xanthine oxidase $(\mathrm{XO})$ is responsible for the oxidation of $6-\mathrm{MP}$ to the inactive 6-thiouric acid.

Levels of the two active metabolites 6-TGN and 6-MMPN are more significant than medication dosage in determining a patient's likelihood of therapeutic response or intolerance. While approximately one-third of patients achieve clinical remission with a lower 6-TGN level, an improved therapeutic response rate has been shown with 6-TGN levels higher than $230 \mathrm{pmol} / 8 \times 10^{8}$ erythrocytes (red blood cells [RBCs]), and

Division of Gastroenterology and Liver Diseases, Department of Internal Medicine, The George Washington University Medical Center,

Washington, DC, USA

Correspondence: Dr Allen L Ginsberg, Professor Emeritus, Division of Gastroenterology and Liver Diseases, Department of Internal Medicine,

The George Washington University Medical Center, 2150 Pennsylvania Avenue Northwest, \#3-405, Washington, DC 20037, USA.

Telephone 202-741-2160, fax 202-741-2169, e-mail aginsberg@mfa.gwu.edu

Received for publication June 2, 2007. Accepted June 25, 2007 


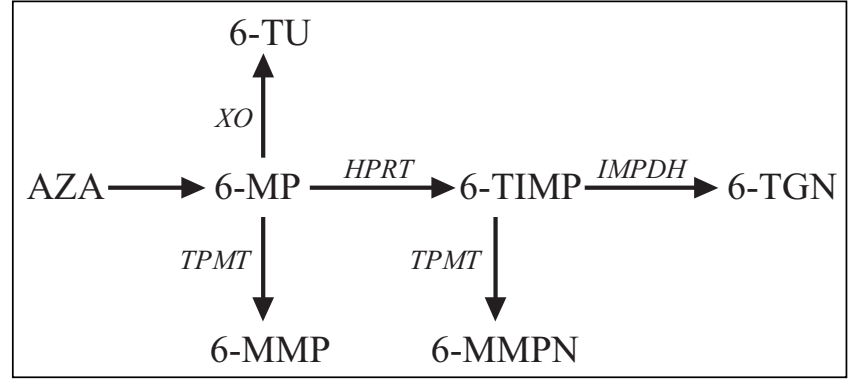

Figure 1) The azathioprine (AZA)/6-mercaptopurine (6-MP) metabolism pathway. 6-MMP 6-Methylmercaptopurine; 6-MMPN 6-Methylmercaptopurine nucleotide; 6-TGN 6-Thioguanine nucleotide; 6-TIMP 6-Thioinosine 5'-monophosphate; 6-TU 6-Thiouric acid; HPRT Hypoxanthine phosphoribosyltransferase; IMPDH Inosine monophosphate dehydrogenase; TPMT Thiopurine methyltransferase; XO Xanthine oxidase. Adapted from reference 4

increased hepatotoxicity is seen with 6-MMPN levels higher than $5700 \mathrm{pmol} / 8 \times 10^{8} \mathrm{RBCs}(3,4)$. A subgroup of patients fails to attain optimal 6-TGN levels despite medication dosage escalation and instead, preferentially shunts to the potentially hepatotoxic metabolite 6-MMPN $(5,6)$.

A retrospective chart review was conducted of inflammatory bowel disease (IBD) patients at our institution who were treated with combined allopurinol and 6-MP. Clinical remission was defined by disease activity scores obtained from detailed outpatient records. The Crohn's Disease Activity Index (CDAI) (7) was used to assess patients with Crohn's disease, and the Simple Clinical Colitis Activity Index (SCCAI) $(8,9)$ was used to assess patients with ulcerative colitis. The institutional review board at our medical centre approved the study, and informed consent was obtained from subjects.

We present the cases of four patients who were unable to achieve clinical remission off of corticosteroids or therapeutic levels of the metabolite 6-TGN despite 6-MP dose escalation (Table 1). Whereas all four patients had demonstrated shunting from 6-TGN to 6-MMPN on high doses of 6-MP, low doses of 6-MP in combination with allopurinol $100 \mathrm{mg}$ daily resulted in optimal metabolite levels in all four patients, with three out of the four patients achieving sustained, steroid-free clinical remission.

\section{CASE PRESENTATIONS}

\section{Case 1}

A 36 -year-old, $120 \mathrm{~kg}$ man with Crohn's colitis that had been diagnosed three years previously was referred for management. The patient complained of eight to 10 semi-formed, nonbloody bowel movements per day. He had been treated in the past with various regimens, including infliximab and a clinical trial of adalimumab, without symptomatic improvement.

The patient was taking $6-\mathrm{MP} 100 \mathrm{mg}(0.83 \mathrm{mg} / \mathrm{kg})$ daily but no corticosteroids, and had normal liver enzyme levels. 6-MP was increased to $150 \mathrm{mg}(1.25 \mathrm{mg} / \mathrm{kg})$. Four weeks later, bloodwork revealed the following levels: 6-TGN, $144 \mathrm{pmol} / 8 \times 10^{8}$ RBCs; 6-MMPN, $5612 \mathrm{pmol} / 8 \times 10^{8} \mathrm{RBCs}$; and alanine aminotransferase (ALT), $99 \mathrm{U} / \mathrm{L}$.

6-MP was then reduced to $50 \mathrm{mg}(0.42 \mathrm{mg} / \mathrm{kg})$ daily. One week later, allopurinol $100 \mathrm{mg}$ daily was started. After two weeks of unchanged symptoms, 6-MP was increased to $75 \mathrm{mg}(0.63 \mathrm{mg} / \mathrm{kg})$. One week later, the 6-TGN level was $275 \mathrm{pmol} / 8 \times 10^{8} \mathrm{RBCs}$ and 6-MMPN was undetectable. Continued symptoms six weeks later despite optimal 6-TGN levels prompted an ileocolonoscopy, which revealed colonic pseudopolyps throughout the colon, histologically quiescent colitis and a normal terminal ileum. A small bowel capsule endoscopy was normal. Simultaneous to these findings, the white blood cell (WBC) count decreased to $2.5 \times 10^{9} / \mathrm{L}$, with an absolute neutrophil count (ANC) of $1.4 \times 10^{9} / \mathrm{L}$. 6-MP and allopurinol were discontinued. Nine days later, the patient developed facial herpes zoster with a WBC count of $3.1 \times 10^{9} / \mathrm{L}$ (ANC $1.3 \times 10^{9} / \mathrm{L}$ ). Antiviral therapy with oral famciclovir was started, and the leukopenia and shingles resolved within one week.

Although the patient did not benefit from combined allopurinol and 6-MP therapy (CDAI score 157), it was believed that the patient's continued loose stools were due not to active inflammation but rather to burnt-out disease. This assessment was based on colonoscopic and histological findings; persistent C-reactive protein measurement of less than $1 \mathrm{mg} / \mathrm{L}$; lack of response to various therapies, including anti-tumour necrosis factor therapy; and symptoms that improved (CDAI score 134) with antidiarrheal medications.

\section{Case 2}

A 30-year-old, $82 \mathrm{~kg}$ man with a six-year history of ulcerative colitis had been only partially controlled on mesalamine and 6-MP $100 \mathrm{mg}(1.22 \mathrm{mg} / \mathrm{kg})$ daily, and had required intermittent use of corticosteroids. In an effort to control symptoms of increased stool frequency, urgency and hematochezia, 6-MP was increased to $125 \mathrm{mg}(1.52 \mathrm{mg} / \mathrm{kg})$; however, this caused an abnormal ALT level of $128 \mathrm{U} / \mathrm{L}$, with a 6-TGN level of $109 \mathrm{pmol} / 8 \times 10^{8} \mathrm{RBCs}$ and a 6-MMPN level of $9432 \mathrm{pmol} / 8 \times 10^{8} \mathrm{RBCs}$.

6-MP was reduced to $50 \mathrm{mg}(0.61 \mathrm{mg} / \mathrm{kg})$ daily. The addition of allopurinol $100 \mathrm{mg}$ daily was delayed until eight weeks later because of the patient's travel. After tolerating combination therapy for two weeks, 6-MP was increased to $75 \mathrm{mg}$ $(0.91 \mathrm{mg} / \mathrm{kg})$ daily. Thirteen days later, bloodwork revealed a 6-TGN level of $294 \mathrm{pmol} / 8 \times 10^{8} \mathrm{RBCs}$, an undetectable level of 6-MMPN and normal liver enzymes. The patient's symptoms markedly improved without the use of corticosteroids; however, after 11 weeks of combination therapy, the patient complained of fatigue and lightheadedness, and was found to have a WBC count of $3.0 \times 10^{9} / \mathrm{L}\left(\right.$ ANC $\left.1.7 \times 10^{9} / \mathrm{L}\right)$. The dosage of 6-MP was reduced to $25 \mathrm{mg}(0.30 \mathrm{mg} / \mathrm{kg})$ while the leukopenia resolved. The patient was ultimately maintained on alternating doses of $25 \mathrm{mg}$ and $50 \mathrm{mg}(0.46 \mathrm{mg} / \mathrm{kg})$ of $6-\mathrm{MP}$, with a resultant 6 -TGN level of $222 \mathrm{pmol} / 8 \times 10^{8} \mathrm{RBCs}$ and an undetectable 6-MMPN level. He maintained clinical remission (SCCAI score 0) without corticosteroids for eight months and subsequently moved out of the country.

\section{Case 3}

A 48-year-old $90 \mathrm{~kg}$ man with ulcerative colitis that had been diagnosed more than 10 years previously had been only partially controlled on oral and rectal mesalamine, 6-MP $150 \mathrm{mg}$ $(1.67 \mathrm{mg} / \mathrm{kg})$ daily and prednisone $10 \mathrm{mg}$ every other day. Over the years, the patient's disease had flared repeatedly when corticosteroids were discontinued. 6-MP metabolite analysis revealed a 6 -TGN level of $82 \mathrm{pmol} / 8 \times 10^{8} \mathrm{RBCs}$ and a 
TABLE 1

Described cases involving combined therapy with 6-mercaptopurine (6-MP) and allopurinol

\begin{tabular}{|c|c|c|c|c|}
\hline Characteristic & Case 1 & Case 2 & Case 3 & Case 4 \\
\hline Age & 36 years & 30 years & 48 years & 21 years \\
\hline Sex & Male & Male & Male & Male \\
\hline Weight & $120 \mathrm{~kg}$ & $82 \mathrm{~kg}$ & $90 \mathrm{~kg}$ & $71 \mathrm{~kg}$ \\
\hline Ethnic background & Caucasian & Caucasian & Caucasian & Indian \\
\hline Diagnosis & Crohn's colitis & Ulcerative colitis & Ulcerative colitis & Ulcerative colitis \\
\hline $\begin{array}{l}\text { Duration of disease before } \\
\text { initiation of allopurinol }\end{array}$ & Three years & Six years & $>10$ years & 14 months \\
\hline Thiopurine methyltransferase & $\begin{array}{l}\text { Not tested (assumed } \\
\text { normal clinically) }\end{array}$ & Normal alleles & $\begin{array}{l}\text { Not tested (assumed } \\
\text { normal clinically) }\end{array}$ & $\begin{array}{l}\text { Not tested (assumed } \\
\text { normal clinically) }\end{array}$ \\
\hline $\begin{array}{l}\text { Shunting demonstrated by } \\
6 \text {-TGN/6-MMPN levels (pmol/ } 8 \times 10^{8} \mathrm{RBCs} \text { ) }\end{array}$ & $134 / 9558$ & $109 / 9432$ & $82 / 27,369$ & $181 / 13,757$ \\
\hline $\begin{array}{l}\text { Justification for allopurinol } \\
\text { combination therapy }\end{array}$ & $\begin{array}{l}\text { Shunting; abnormal ALT } \\
\text { levels; failed multiple other } \\
\text { therapies, including anti-TNF }\end{array}$ & $\begin{array}{l}\text { Shunting; abnormal ALT } \\
\text { levels; steroid dependent }\end{array}$ & $\begin{array}{l}\text { Shunting; steroid } \\
\text { dependent }\end{array}$ & $\begin{array}{l}\text { Shunting, abnormal } \\
\text { ALT levels, steroid } \\
\text { dependent }\end{array}$ \\
\hline Concomitant IBD therapy & - & Mesalamine & Mesalamine & Mesalamine \\
\hline 6-MP dose prior to initiating allopurinol & $150 \mathrm{mg}(1.25 \mathrm{mg} / \mathrm{kg})$ & $125 \mathrm{mg}(1.52 \mathrm{mg} / \mathrm{kg})$ & $150 \mathrm{mg}(1.67 \mathrm{mg} / \mathrm{kg})$ & $100 \mathrm{mg}(1.41 \mathrm{mg} / \mathrm{kg})$ \\
\hline $\begin{array}{l}\text { 6-MP dose in combination with allopurinol } \\
\text { to achieve optimal metabolites }\end{array}$ & $50 \mathrm{mg}^{*}(0.42 \mathrm{mg} / \mathrm{kg})$ & $50 \mathrm{mg}^{\dagger}(0.61 \mathrm{mg} / \mathrm{kg})$ & $50 \mathrm{mg}(0.56 \mathrm{mg} / \mathrm{kg})$ & $25 \mathrm{mg}(0.35 \mathrm{mg} / \mathrm{kg})$ \\
\hline $\begin{array}{l}\text { Optimal 6-TGN/6-MMPN levels achieved } \\
\left.\text { with combination therapy (pmol/ } 8 \times 10^{8} \mathrm{RBCs}\right)\end{array}$ & 275/undetectable & 294/undetectable & 319/undetectable & 357/undetectable \\
\hline $\begin{array}{l}\text { Time from initiation of allopurinol } \\
\text { to optimal metabolites }\end{array}$ & 25 days & 28 days & 69 days & 28 days \\
\hline Adverse events & $\begin{array}{l}\text { Zoster rash associated with } \\
\text { transient leukopenia }\end{array}$ & Transient leukopenia & - & - \\
\hline Clinical outcome & $\begin{array}{l}\text { 6-MP plus allopurinol ceased } \\
\text { because of lack of benefit } \\
\text { to patient; patient later } \\
\text { diagnosed with } \\
\text { nonalcoholic steatohepatitis }\end{array}$ & $\begin{array}{l}\text { Continued 6-MP plus } \\
\text { allopurinol; in steroid-free } \\
\text { clinical remission at least } \\
\text { eight months }\end{array}$ & $\begin{array}{l}\text { Continued 6-MP plus } \\
\text { allopurinol; in steroid- } \\
\text { free clinical remission } \\
\text { for } 12 \text { months as of } \\
\text { chart review }\end{array}$ & $\begin{array}{l}\text { Continued 6-MP plus } \\
\text { allopurinol; in steroid- } \\
\text { free clinical remission } \\
\text { for nine months as of } \\
\text { chart review }\end{array}$ \\
\hline
\end{tabular}

${ }^{*}$ Although the patient was taking $75 \mathrm{mg}$ at the time of the blood draw, the timing, shortly after increasing 6-MP from $50 \mathrm{mg}$ to $75 \mathrm{mg}$, suggests that the lower dose of 6-MP was reflected in the metabolite levels; the patient was ultimately maintained on alternating doses of $25 \mathrm{mg}$ and $50 \mathrm{mg}(0.46 \mathrm{mg} / \mathrm{kg}$ ) with a 6 -thioguanine nucleotide (6-TGN) level of 222 pmol/8 $\times 10^{8}$ red blood cells (RBCs) and undetectable 6-methylmercaptopurine nucleotide (6-MMPN). ALT Alanine aminotransferase; Anti-TNF Anti-tumour necrosis factor; IBD Inflammatory bowel disease

6-MMPN level of $27,369 \mathrm{pmol} / 8 \times 10^{8}$ RBCs. Despite this markedly elevated 6-MMPN level, the patient always had normal liver enzyme concentrations.

In an effort to discontinue prednisone and obtain better disease control, 6 -MP was reduced to $25 \mathrm{mg}(0.28 \mathrm{mg} / \mathrm{kg})$ for one month, during which time a flare was experienced that was quickly controlled with increased prednisone. Allopurinol $100 \mathrm{mg}$ daily was then added. After four weeks of combined therapy, the 6 -TGN level was $146 \mathrm{pmol} / 8 \times 10^{8} \mathrm{RBCs}$ and 6-MMPN was undetectable. 6-MP was increased to $50 \mathrm{mg}$ $(0.56 \mathrm{mg} / \mathrm{kg})$ daily, and four weeks later, the 6-TGN level was $319 \mathrm{pmol} / 8 \times 10^{8} \mathrm{RBCs}$ and 6-MMPN remained undetectable. The patient was successfully tapered off of prednisone for the first time in many years, and he has maintained steroid-free clinical remission (SCCAI score 1) for 12 months as of the present chart review.

\section{Case 4}

A 21 -year-old, $71 \mathrm{~kg}$ man with ulcerative colitis that had been diagnosed 14 months previously was referred for management. The patient had required mesalamine and high-dose steroids to achieve clinical remission. Repeated flares on tapering doses of corticosteroids prompted 6-MP therapy. Escalating doses of 6-MP had been used ineffectively in an effort to taper corticosteroids. 6-MP $100 \mathrm{mg}(1.41 \mathrm{mg} / \mathrm{kg})$ resulted in an abnormal ALT concentration of $208 \mathrm{U} / \mathrm{L}$, with a 6-TGN level of $181 \mathrm{pmol} / 8 \times 10^{8} \mathrm{RBCs}$ and a 6 -MMPN level of $13,757 \mathrm{pmol} / 8 \times 10^{8} \mathrm{RBCs}$.

6-MP was then reduced to $25 \mathrm{mg}(0.35 \mathrm{mg} / \mathrm{kg})$ daily while the patient was continued on prednisone $40 \mathrm{mg}$ daily. Four weeks later, allopurinol $100 \mathrm{mg}$ daily was added. After four weeks of combination therapy with allopurinol and 6-MP, the 6-TGN level was $357 \mathrm{pmol} / 8 \times 10^{8} \mathrm{RBCs}, 6$-MMPN was undetectable and liver enzymes were normal. The patient was then successfully tapered off of prednisone for the first time since diagnosis, and he has remained in steroid-free clinical remission (SCCAI score 0) for nine months as of the present chart review.

\section{DISCUSSION}

The interaction between allopurinol and 6-MP/AZA has been recognized since the 1960 s. Combined therapy is well reported in the oncology literature to enhance the therapeutic efficacy of 6-MP while avoiding the potentially nephrotoxic 
effects of purine overload caused by rapid destruction of neoplastic tissue by chemotherapy (10-12). Combined allopurinol and 6-MP/AZA has also been reported to provide benefit in renal transplantation (13). Recently, Sparrow et al $(14,15)$ reported success with allopurinol in increasing 6-TGN levels to the therapeutic range while decreasing 6-MMPN in IBD patients previously refractory to 6-MP/AZA because of shunting to 6-MMPN. A short-term (three-month) clinical improvement, as well as normalization of liver enzymes, was also noted $(14,15)$.

Allopurinol is an inhibitor of $\mathrm{XO}$, which is located in the liver and intestinal mucosa. Allopurinol decreases the yield of the pathway of 6-MP to inactive 6-thiouric acid and inhibits first-pass metabolism. This thereby increases the fraction of the drug available for anabolism to the active nucleotide forms 6-TGN and 6-MMPN $(16,17)$.

In a study of allopurinol and oral 6-MP, there was no effect of adding allopurinol on time to peak plasma concentration or elimination half-life of 6-MP. However, it was shown that the mean peak plasma concentration and area under the curve of 6-MP increased nearly fivefold (10). The improved bioavailability of 6-MP results in higher 6-TGN levels. This explains the well-known adverse event of bone marrow suppression $(18-20)$. For this reason, the literature has historically urged that when combined with allopurinol, the dose of 6-MP should be significantly reduced $(10-12,20,21)$.

It has recently been suggested that the principal metabolites within 6-TGN are the active 6-thioguanosine triphosphate (6-TGTP), which results in T-cell apoptosis, and the inactive 6-thioguanosine diphosphate (6-TGDP) (22,23). Patients with high 6-TGN levels made up predominantly of 6-TGTP have been shown to have improved outcomes compared with those with high 6-TGN made up predominantly of 6-TGDP (23). The effect that allopurinol or the lower dose of 6-MP used in combination therapy has on the newly described 6-TGTP and 6-TGDP metabolites is unclear. Our clinical experience suggests that perhaps 6-TGTP production is augmented.

In patients with established preferential shunting toward 6-MMPN, the use of allopurinol should theoretically lead to a further increase in 6-MMPN. Our findings confirm those of Sparrow et al $(14,15)$ indicating that this is not so. In fact, levels of 6-MMPN in our patients declined from potentially toxic to undetectable levels. The effect of allopurinol on 6-MMPN may logically be explained by the inhibition of TPMT. Unpublished data, however, have demonstrated no effect of allopurinol on TPMT in vitro or in vivo $(15,24)$. Duley et al (21) propose that perhaps the addition of allopurinol provides oxypurinol metabolites, which antagonize TPMT, although unpublished experiments have not found this to be the case (15). Another possibility is that a usually omnipresent coenzyme (perhaps XO) is necessary for TPMT to metabolize 6-MP to 6-MMPN.

Whatever the mechanism, the addition of allopurinol to a low dose of 6-MP appears to be an effective means of shifting the metabolism away from 6-MMPN toward 6-TGN. This should increase the likelihood of clinical response and eliminate hepatotoxicity associated with increased levels of 6-MMPN.

6-MMPN levels higher than $5700 \mathrm{pmol} / 8 \times 10^{8} \mathrm{RBC}$ are associated with an increased risk of abnormal liver enzymes; however, the mechanism responsible for this is unknown.
6-MMPN is not itself hepatotoxic, as shown by the third patient in the present report, who had a markedly elevated 6-MMPN level $\left(27,369 \mathrm{pmol} / 8 \times 10^{8} \mathrm{RBCs}\right)$ without serological evidence of hepatocellular injury.

Regarding the use of 6-MP with allopurinol, a word of caution is appropriate. The risk of leukopenia and its complications with this combination is of a different order of magnitude than when 6-MP is used alone. Our first two patients developed symptomatic leukopenia despite careful monitoring. In hindsight, both patients likely achieved optimal thioguanine metabolite levels at a dose of $50 \mathrm{mg}$ 6-MP, and the increase of 6-MP to $75 \mathrm{mg}$ was probably responsible for the leukopenia.

In their initial publication, Sparrow et al (14) expressed a theoretical concern about nodular regenerative hyperplasia (NRH), though this concern was not shared by Duley et al (21). Although there have been case reports of AZA associated with NRH (25), this concern likely derives from studies in which the medication 6-thioguanine (6-TG) was associated with NRH (26-29). While vascular compromise is hypothesized to be involved in NRH, the etiology of the association between 6-TG and NRH remains unclear. NRH does not appear to be a significant concern with the use of conventional 6-MP/AZA therapy. Moreover, we cannot presume that the 6-TGN derived from the metabolism of 6-MP and the 6-TGN produced by $6-\mathrm{TG}$ are biochemically the same (27). Perhaps $\mathrm{NRH}$ is associated with the very high levels of 6 -TGN seen with the direct use of 6-TG.

Our experience, combined with the literature on AZA/6-MP plus allopurinol therapy, leads us to make several recommendations. This combination therapy is intended only for patients with low, subtherapeutic levels of 6-TGN associated with high levels of 6-MMPN despite AZA/6-MP dose escalation. Such patients would be expected to have normal or high levels of the enzyme TPMT. Patient selection, with an emphasis on compliance, is also critical to ensure safety and success. We suggest a reduction in the patient's 6-MP to a low dose such as $25 \mathrm{mg}$ for two to four weeks. Despite suboptimal levels of 6-TGN, the patient may have derived some benefit from the 6-MP, and it may be necessary to control disease activity with corticosteroids during this 'washout' period. Allopurinol $100 \mathrm{mg}$ daily can then be added, and we recommend weekly analysis of the complete blood count and liver enzymes. While balancing a clinical need for monitoring with the reality that the patient's insurance carrier may not cover these sophisticated tests, it is reasonable to assess 6-MP metabolites after four weeks of combination therapy, as in our third and fourth cases. Checking metabolites earlier than two weeks after starting or changing the dosage of 6-MP, as in the first and second cases, may be misleading, as 6-TGN concentrations are reported to reach a steady state in two to three weeks (30-32).

If the level of 6 -TGN remains suboptimal, the dosage of 6-MP can be increased, again monitoring bloodwork weekly, until the metabolites are rechecked in another four weeks. Because corticosteroids can be responsible for an elevated WBC count, careful monitoring for leukopenia is also required when corticosteroids are tapered. Our cases suggest that optimal metabolite levels are achievable within approximately one to two months (mean 38 days), with 6-MP doses in the approximate range of 0.35 to $0.61 \mathrm{mg} / \mathrm{kg}$ (mean $0.49 \mathrm{mg} / \mathrm{kg})$. 


\section{CONCLUSIONS}

The combination of allopurinol $100 \mathrm{mg}$ daily with low-dose 6-MP provides a therapeutic option not previously available to the subset of IBD patients unable to benefit from traditional 6-MP dosing because of preferential shunting to 6-MMPN. This approach requires a high degree of caution using a low

\section{REFERENCES}

1. Present DH, Korelitz BI, Wisch N, Glass JL, Sachar DB, Pasternack BS. Treatment of Crohn's disease with 6-mercaptopurine. A long-term, randomized, double-blind study. N Engl J Med 1980;302:981-7.

2. Weinshilboum RM, Sladek SL. Mercaptopurine pharmacogenetics: Monogenic inheritance of erythrocyte thiopurine methyltransferase activity. Am J Hum Genet 1980;32:651-62.

3. Osterman MT, Kundu R, Lichtenstein GR, Lewis JD. Association of 6-thioguanine nucleotide levels and inflammatory bowel disease activity: A meta-analysis. Gastroenterology 2006;130:1047-53.

4. Dubinsky MC, Lamothe S, Yang HY, et al. Pharmacogenomics and metabolite measurement for 6-mercaptopurine therapy in inflammatory bowel disease. Gastroenterology 2000;118:705-13.

5. Dubinsky MC, Yang H, Hassard PV, et al. 6-MP metabolite profiles provide a biochemical explanation for 6-MP resistance in patients with inflammatory bowel disease. Gastroenterology 2002;122:904-15.

6. Cuffari C, Dassopoulos T, Turnbough L, Thompson RE, Bayless TM. Thiopurine methyltransferase activity influences clinical response to azathioprine in inflammatory bowel disease. Clin Gastroenterol Hepatol 2004:2:410-7.

7. Best WR, Becktel JM, Singleton JW, Kern F Jr. Development of a Crohn's disease activity index. National Cooperative Crohn's Disease Study. Gastroenterology 1976;70:439-44.

8. Walmsley RS, Ayres RC, Pounder RE, Allan RN. A simple clinical colitis activity index. Gut 1998;43:29-32.

9. Higgins PD, Schwartz M, Mapili J, Krokos I, Leung J, Zimmermann EM. Patient defined dichotomous end points for remission and clinical improvement in ulcerative colitis. Gut 2005;54:782-8.

10. Zimm S, Collins JM, O’Neill D, Chabner BA, Poplack DG. Inhibition of first-pass metabolism in cancer chemotherapy: Interaction of 6-mercaptopurine and allopurinol. Clin Pharmacol Ther 1983;34:810-7.

11. Rundles RW. Effects of allopurinol on 6-mercaptopurine therapy in neoplastic diseases. Ann Rheum Dis 1966;25(6 Suppl):655-6.

12. Coffey JJ, White CA, Lesk AB, Rogers WI, Serpick AA. Effect of allopurinol on the pharmacokinetics of 6-mercaptopurine (NSC 755) in cancer patients. Cancer Res 1972;32:1283-9.

13. Chocair P, Duley J, Simmonds HA, et al. Low-dose allopurinol plus azathioprine/cyclosporin/prednisolone, a novel immunosuppressive regimen. Lancet 1993;342:83-4.

14. Sparrow MP, Hande SA, Friedman S, et al. Allopurinol safely and effectively optimizes tioguanine metabolites in inflammatory bowel disease patients not responding to azathioprine and mercaptopurine. Aliment Pharmacol Ther 2005;22:441-6.

15. Sparrow MP, Hande SA, Friedman S, Cao D, Hanauer SB. Effect of allopurinol on clinical outcomes in inflammatory bowel disease nonresponders to azathioprine or 6-mercaptopurine. Clin Gastroenterol Hepatol 2007;5:209-14.

16. Sasaki H, Tsuru K, Nakamura J, Konishi R, Shibasaki J. Effect of allopurinol on the intestinal absorption of 6-mercaptopurine in rats. J Pharmacobiodyn 1987;10:697-702.

17. Olah T, Regely K, Mandi Y. The inhibitory effects of allopurinol on the production and cytotoxicity of tumor necrosis factor. Naunyn Schmiedebergs Arch Pharmacol 1994;350:96-9. dose of 6-MP/AZA, with frequent monitoring and careful patient selection. Additional research is necessary to establish the long-term safety of this approach.

ACKNOWLEDGMENTS: The authors thank Dr M Aamir Ali, Dr Showkat Bashir and Dr Marie L Borum for their assistance.

18. Zimm S, Collins JM, Riccardi R, et al. Variable bioavailability of oral mercaptopurine. Is maintenance chemotherapy in acute lymphoblastic leukemia being optimally delivered? N Engl J Med 1983;308:1005-9.

19. Zazgornik J, Hruby K, Schmidt P, Kopsa H, Pils P. [Hemolysis after combined azathioprine and allopurinol therapy.] Acta Med Austriaca 1979;6:197-9

20. Berns A, Rubenfeld S, Rymzo WT Jr, Calabro JJ. Hazard of combining allopurinol and thiopurine. N Engl J Med 1972;286:730-1.

21. Duley JA, Chocair PR, Florin TH. Observations on the use of allopurinol in combination with azathioprine or mercaptopurine. Aliment Pharmacol Ther 2005;22:1161-2.

22. Tiede I, Fritz G, Strand S, et al. CD28-dependent Racl activation is the molecular target of azathioprine in primary human CD4+ T lymphocytes. J Clin Invest 2003;111:1133-45.

23. Neurath MF, Kiesslich R, Teichgraber U, et al. 6-thioguanosine diphosphate and triphosphate levels in red blood cells and response to azathioprine therapy in Crohn's disease. Clin Gastroenterol Hepatol 2005;3:1007-14.

24. Sparrow M, Hande SA, Friedman S, Cao D, Hanauer SB. Optimization of 6-thioguanine production by allopurinol in inflammatory bowel disease patients not responding to azathioprine/6-mercaptopurine leads to improved disease activity, reduced corticosteroid requirements and normalization of liver enzymes. Gastroenterology 2006;130:A142. (Abst)

25. Daniel F, Cadranel JF, Seksik P, et al. Azathioprine induced nodular regenerative hyperplasia in IBD patients. Gastroenterol Clin Biol 2005;29:600-3.

26. De Bruyne R, Portmann B, Samyn M, et al. Chronic liver disease related to 6-thioguanine in children with acute lymphoblastic leukaemia. J Hepatol 2006;44:407-10.

27. Dubinsky MC, Feldman EJ, Abreu MT, Targan SR, Vasiliauskas EA Thioguanine: A potential alternate thiopurine for IBD patients allergic to 6-mercaptopurine or azathioprine. Am J Gastroenterol 2003;98:1058-63.

28. Dubinsky MC, Vasiliauskas EA, Singh H, et al. 6-thioguanine can cause serious liver injury in inflammatory bowel disease patients. Gastroenterology 2003;125:298-303.

29. Shastri S, Dubinsky MC, Fred Poordad F, Vasiliauskas EA, Geller SA. Early nodular hyperplasia of the liver occurring with inflammatory bowel diseases in association with thioguanine therapy. Arch Pathol Lab Med 2004;128:49-53.

30. Sandborn WJ, Tremaine WJ, Wolf DC, et al. Lack of effect of intravenous administration on time to respond to azathioprine for steroid-treated Crohn's disease. North American Azathioprine Study Group. Gastroenterology 1999;117:527-35. (Comment in 2000;118:1281-2).

31. Lennard L, Lilleyman JS. Variable mercaptopurine metabolism and treatment outcome in childhood lymphoblastic leukemia. J Clin Oncol 1989;7:1816-23. (Erratum in 1990;8:567).

32. Bergan S, Rugstad HE, Bentdal O, Endresen L, Stokke O. Kinetics of mercaptopurine and thioguanine nucleotides in renal transplant recipients during azathioprine treatment. Ther Drug Monit 1994;16:13-20. 


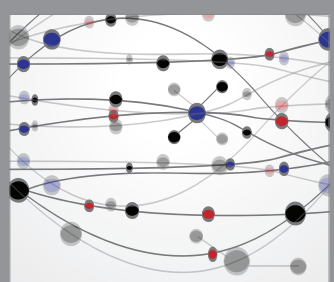

The Scientific World Journal
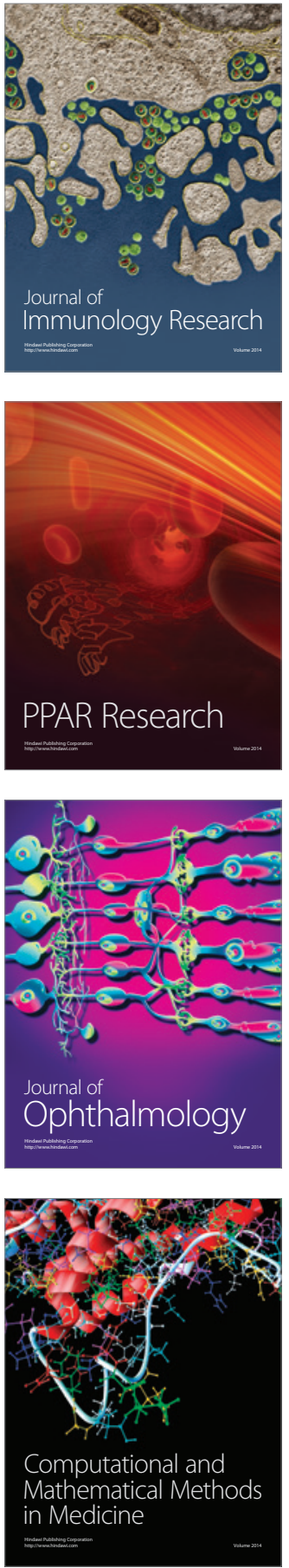

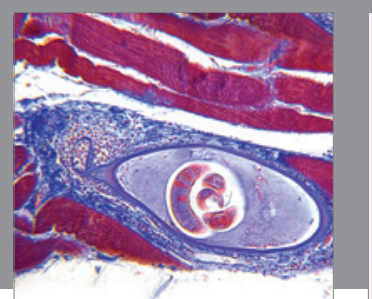

Gastroenterology Research and Practice

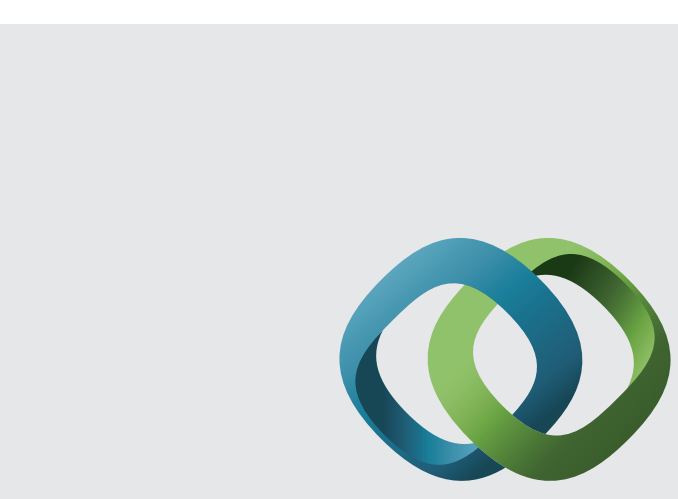

\section{Hindawi}

Submit your manuscripts at

http://www.hindawi.com
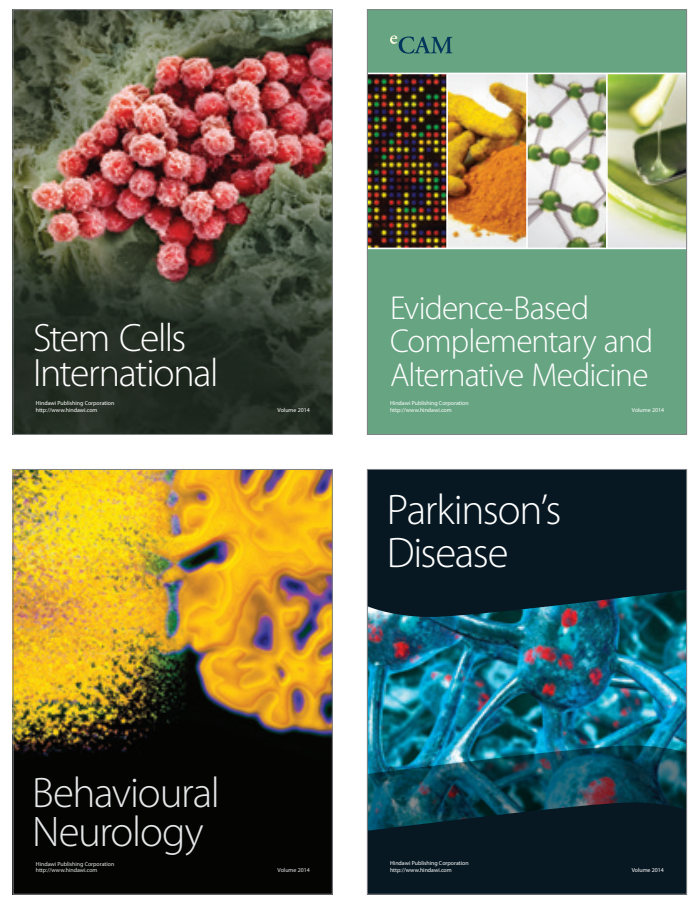
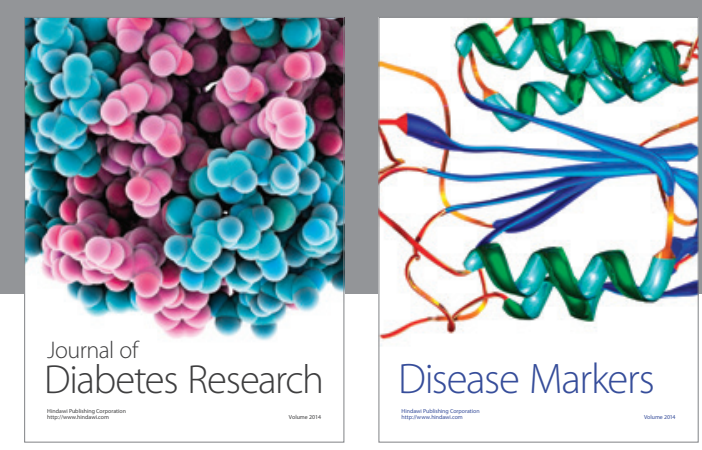

Disease Markers
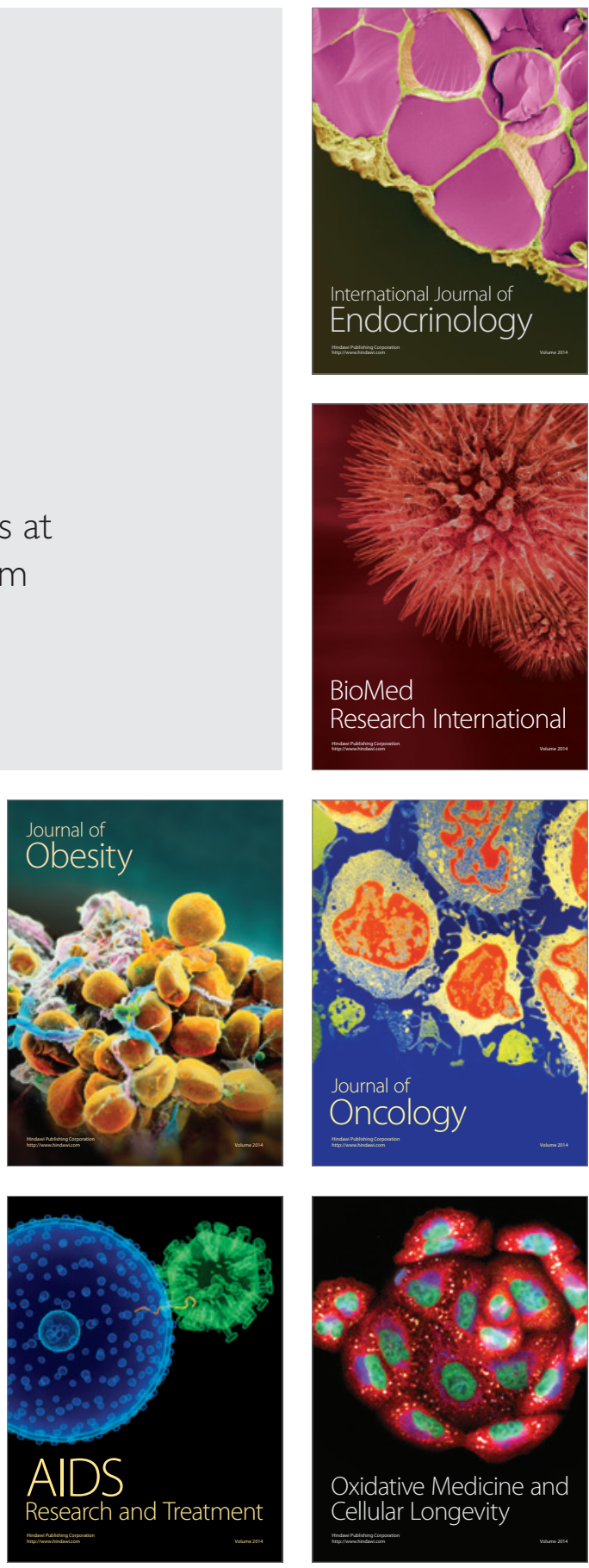